\title{
Sire predicted transmitting ability for conformation and yield traits and previous lactation incidence of foot lesions as risk factors for the incidence of foot lesions in Holstein cows
}

\author{
G. Oikonomou, ${ }^{*}$ N. B. Cook, $†$ and R. C. Bicalho*1 \\ *Department of Population Medicine and Diagnostic Sciences, College of Veterinary Medicine, Cornell University, Ithaca, NY 14853 \\ †Department of Medical Sciences, School of Veterinary Medicine, University of Wisconsin-Madison, Madison 53706
}

\begin{abstract}
The aims of the present study were (1) to investigate the repeatability of foot lesions [sole ulcers (SU), white line disease (WLD), and digital dermatitis (DD)] across multiple lactations, (2) to evaluate the effect of foot lesions on cow survivability and milk production across multiple lactations, and (3) to investigate the role of sire predicted transmitting ability (PTA) for conformation and production traits as risk factors for the incidence of SU, WLD, and DD. Data were collected from a dairy farm located in Cayuga County, New York. A total of 11,442 cows having first calved during the period from May 13, 2001, to March 26, 2012, were enrolled in the study. Data regarding sire genetic evaluations were obtained from DairyBulls.com (http://www. DairyBulls.com). Lameness was detected and treated and lesions were recorded into a dairy record database (DairyCOMP 305; Valley Agricultural Software, Tulare, CA) by trained farm employees. All demographic, production, and foot lesion data were extracted from DairyCOMP 305 and merged with the sires' PTA information to form a unique database. Mixed logistic regression, general linear mixed, and multivariable Cox proportional hazards models were used to analyze the data. Sole ulcers, WLD, and DD incidence was significantly higher for cows affected with SU, WLD, or DD in previous lactations. Cows affected with WLD or DD during the first lactation had significantly higher WLD or DD incidence during the second and the third lactations. Cows affected with SU or WLD during their first lactation had significantly lower milk production during the second lactation and cows diagnosed with SU, WLD, or DD during their second lactation had higher second-lactation mature-equivalent 305-d milk yield. Sire PTA for milk and protein yield were significantly associated with the incidence of SU, WLD, and DD and incidence of SU and WLD, respectively.
\end{abstract}

Received October 24, 2012.

Accepted February 22, 2013.

${ }^{1}$ Corresponding author: rcb28@cornell.edu
Sire PTA for several conformation traits were found to be associated with SU, WLD, and DD incidence. Cows that were affected with SU or WLD during their first lactation were at 1.18 or 1.43 higher hazard of culling than unaffected cows, respectively. In summary, we conclude that $\mathrm{SU}, \mathrm{WLD}$, and DD are highly repeatable across lactations and that high genetic merit for milk and protein production as well as milk production (phenotype) were significantly associated with higher risk of SU, WLD, and DD. Additionally, sire PTA for several conformation traits were significantly associated with their daughters' foot lesion incidence.

Key words: lameness, dairy cow, predicted transmitting ability, foot lesion

\section{INTRODUCTION}

Lameness is a debilitating and painful condition that represents a serious animal welfare issue (von Keyserlingk et al., 2009). Additionally it is extremely costly for the dairy industry, causing significant milk production losses, decreasing reproductive efficiency, and increasing risk of involuntary culling (Cha et al., 2010).

Lameness effects on cow production or survivability have been usually estimated for the lactation (LACT) period during which a lameness event was recorded. Bicalho et al. (2008) reported milk production losses due to lameness that reached $424 \mathrm{~kg}$ per cow per 305-d LACT. Booth et al. (2004) and Bicalho et al. (2007) reported that lameness significantly increased the risk of culling. Both studies also used data regarding the LACT period during which a lameness event was recorded. More recently, Machado et al. (2010) reported that claw horn disruption lesions (CHDL) at drying off had negative effects on reproduction and survivability during the subsequent LACT. Additionally, it was recently shown that CHDL at drying off is an important risk factor for lameness during the subsequent LACT (Machado et al., 2011). Hirst et al. (2002) also reported that cows lame during their first LACT had a significantly increased hazard for lameness during the 
second LACT compared with cows not lame during their first LACT.

Low-to-moderate heritability estimates have been reported for clinical lameness (Boettcher et al., 1998), specific foot lesions (van der Waaij et al., 2005; van der Linde et al., 2010; Oberbauer et al., 2013), and locomotion scores (Onyiro et al., 2008), suggesting that genetic selection could have a significant role to play in the alleviation of the impact of lameness. Information on lameness or specific foot lesions is not routinely collected in most countries. However, conformation traits are routinely recorded and several studies have shown considerable genetic correlations between feet and leg conformation or even udder conformation and foot health traits (van der Waaij et al., 2005; Onyiro et al., 2008; van der Linde et al., 2010), whereas other studies (Swalve et al., 2008; Uggla et al., 2008) concluded that these genetic correlations were small. A cow's genetic potential for milk production has also been associated with lameness. Van Dorp et al. (1998) reported a positive genetic correlation between milk yield and clinical lameness (diagnosed by the farmer or a veterinarian). Sire breeding values for conformation and production traits could, therefore, be significant risk factors for their daughters' susceptibility to lameness, but this is yet to be investigated.

The aims of the present study were (1) to investigate the repeatability of foot lesions [sole ulcers (SU), white line disease (WLD), and digital dermatitis (DD)] across multiple LACT, (2) to evaluate the effect of foot lesions on cow survivability and milk production across multiple LACT, and (3) to investigate the role of sire predicted transmitting abilities (PTA) for conformation and production traits as risk factors for their daughters' foot lesions.

\section{MATERIALS AND METHODS}

\section{Experimental Design}

Data were collected from a dairy farm located in Cayuga County, New York. This farm was selected because of its long-standing relationship with the Ambulatory and Production Medicine Clinic at Cornell University (Ithaca, NY). The farm milked 2,800 Holstein cows 3 times daily in a double 52-stall parallel milking parlor. Lactating cows were housed in 6-rows freestall barns with concrete stalls covered with rubber mattresses and bedded with recycled composted manure solids. Maximum cow density was 1 cow per stall at all times. The pen alleys had grooved-concrete flooring and were cleaned by automatic scrapers; all walkways to and from the milking barn and holding pen were covered with rubber. Dry cows were housed in freestall barns and stalls were deep bedded with composted manure solids. Footbaths were located in the exit lanes of the milking parlor. The footbath consisted of a $5 \%$ formalin solution applied at least 4 times weekly according to labor schedule and availability. Lactating cows were fed 3 times daily a TMR consisting of approximately $55 \%$ forage (corn silage, alfalfa haylage, and wheat straw) and $45 \%$ concentrate (cornmeal, soybean meal, canola, cottonseed, and citrus pulp). All lactating cows were scheduled to receive routine hoof trimming twice yearly. A protocol created using DairyCOMP 305 software (Valley Agricultural Software, Tulare, CA) prompted trimming for lactating cows $150 \mathrm{~d}$ after the previous routine hoof trimming. Furthermore, all cows received routine hoof trimming at dry off. Trained farm employees observed cows walking into the milking parlor and recorded the identification (ID) number of visually lame cows daily. Visually lame cows were then directed to the in-house hoof trimmers for therapeutic hoof trimming. Farm employees trimming the cows were all trained by members of the Ambulatory and Production Medicine Clinic at Cornell University and recorded every lesion they observed during every trimming. Sole ulcers, WLD, and DD were defined following the descriptions of Guard (2008). Farm employees' recordings were daily inputted into the DairyCOMP 305 software and obtained for analysis.

Cows that had their first calving during the period from May 13, 2001, to March 26, 2012, were enrolled in the study. Only cows with available information for at least their first entire LACT and available sire information were kept in the study database. Eventually, 11,442 cows were included in the data analysis. These cows were daughters of 217 sires; the average number of daughters per sire was 52.7 , with the maximum number being 416 and the minimum 1 . Sire ID was extracted from DairyCOMP 305 software and was used to locate each sire in the DairyBulls.com database (http://www. DairyBulls.com). Information regarding each sire's genetic evaluation that was obtained from DairyBulls. com (April 2012 evaluations; official US Department of Agriculture genetic base) regarded the following: PTA for fat yield, fat percentage, milk yield (MY), protein yield (PY), protein percentage, SCC, and standardized PTA for stature, strength (STR), body depth, dairy form (DF), rump angle, thurl width (THRLW), feet and legs score, rear legs side view, rear legs rear view (RLRV), foot angle (FA), fore udder attachment (FUA), rear udder height (RUH), rear udder width, udder cleft, and udder depth. The software MedCalc version 10.4.0.0 (MedCalc Software bvba, Mariakerke, Belgium) was used to categorize cows into terciles based on their sire value for each of the traits described above. 
The DairyCOMP 305 software was used for the acquisition of the following information: mature equivalent 305-d (ME305) MY for each LACT of each cow, year of each cow's birth (YB), and age in days that a cow was culled or died (AGEMAX; if a cow was still alive at the end of the data collection, AGEMAX stood for her age at the end of data collection). The data extracted from DairyCOMP 305 was then merged with the foot lesion records and the sire information database that was created with data from DairyBulls.com using JMP software (SAS Institute Inc., Cary, NC).

\section{Statistical Analysis}

Descriptive statistics and univariate analysis were undertaken in SAS (SAS Institute Inc.) using PROC FREQ and UNIVARIATE. To facilitate analysis and interpretation of results, the following variables were categorized: cow sire PTA values for different traits (1, 2 , and 3 for cows categorized in the low, medium, or high tercile, respectively), LACT number $(1,2,3$, and $4 ; 4$ in certain analyses included data regarding the fourth-and-greater LACT numbers).

To evaluate the association of SU, WLD, and DD incidence during the first, second, or third LACT with $\mathrm{SU}, \mathrm{WLD}$, or DD incidence during the subsequent LACT, multivariable mixed logistic regression models were fitted to the data using PROC GLIMMIX of SAS. The variable YB was included in all models. For example, to evaluate the effect of SU incidence during the first LACT (SU1 = 1 for cows affected with SU in the first LACT and 0 for cows not affected with SU in the first LACT) on the incidence of $\mathrm{SU}$ in the subsequent $\mathrm{LACT}$, the variables $\mathrm{YB}, \mathrm{SU}$, and the interaction between SU1 and LACT were offered to the model. Sole ulcer incidence during LACT 2,3 , or $\geq 4$ was the dependent variable. Sole ulcer, WLD, and DD incidences were longitudinally collected (multiple-LACT data) and were treated as repeated measurements by including the cow ID number as a random effect in all models. Adjusted (for all variables offered to each model) probabilities of lesions were obtained using the LSMEANS statement.

To evaluate the association of sire PTA for various traits with $\mathrm{SU}$, WLD, or DD incidence, 3 multivariable mixed logistic regression models were fitted to the data using PROC GLIMMIX of SAS. The following independent variables were entered into the model: PTA for fat yield, fat percentage, MY, PY, protein percentage, SCC, standardized PTA for stature, STR, body depth, DF, rump angle, THRLW, feet and legs score, rear legs side view, RLRV, FA, FUA, RUH, rear udder width, udder cleft, udder depth, AGEMAX and YB. Variables were removed from the model manually in a stepwise manner and only variables with $P<0.05$ were kept in the final model. Two-way interactions between the categorical independent variables and LACT were added to the model. SU, WLD, and DD incidences were longitudinally collected (multiple-LACT data) and were treated as repeated measurements by including the cow ID number as a random effect in all models. Adjusted (for all variables offered to each model) probabilities of lesions were obtained using the LSMEANS statement.

To assess the association of SU, WLD, and DD incidence during the first or the second LACT (SU1, WLD1, and DD1 or SU2, WLD2, and DD2) with multiple-LACT ME305 MY, a general linear mixed model was fitted to the data using PROC MIXED of SAS. The following independent variables were offered to the model: SU1, SU2, WLD1, WLD2, DD1, DD2, and their interaction with LACT. Year of birth and AGEMAX were also offered to the model. The ME305 MY was longitudinally collected (multiple-LACT data) and, therefore, treated as a repeated measurement; the error term was modeled by imposing a first-order autoregressive covariance structure to account appropriately for the within-cow correlation of milk measurements. A similar model was built to evaluate the association of all lesions incidence during the first 3 LACT with ME305 MY.

The association of SU, WLD, and DD incidence during the first LACT (SU1, WLD1, and DD1, respectively) with cow survivability was evaluated with a multivariable Cox proportional hazards model, using PROC PHREG of SAS. Cows were right censored if they were still alive by the end of data collection. Variables offered to the model were SU1, WLD1, DD1, and first-LACT ME305 MY. For all models, variables and their respective interaction terms were retained in the model when their $P$-values were $<0.05$.

\section{RESULTS}

Mean sire PTA per different tercile for each analyzed trait are shown in Table 1 . Incidences of SU, WLD, and DD and mean ME305 MY during the first 5 LACT are shown in Table 2. Sole ulcer and WLD incidence was lower during the first LACT and reached a maximum of 22.8 and $12.4 \%$, respectively, during the fourth LACT. On the other hand, DD incidence was highest during the second LACT (11.4\%) and gradually decreased, reaching the lowest LACT incidence of $6.3 \%$ during the fifth LACT.

Adjusted (for all variables offered to each model) incidence of WLD, SU, or DD by cow LACT, for cows that were affected (1) or not (0) with WLD, SU, or DD 
Table 1. Mean sire predicted transmitting ability per tercile for each analyzed trait

\begin{tabular}{lccc}
\hline & \multicolumn{2}{c}{ Mean sire predicted transmitting ability per tercile } \\
\cline { 2 - 4 } Trait & 1 & 2 & 3 \\
\hline Milk yield & 318.34 & 822.11 & $1,409.1$ \\
Fat yield & 5.53 & 35.24 & 61.13 \\
Protein yield & 11.85 & 28.24 & 43.18 \\
Protein percentage & -0.04 & 0.01 & 0.05 \\
Fat percentage & -0.08 & 0.01 & 0.12 \\
Stature & -1.69 & -0.45 & 0.65 \\
Strength & -1.64 & -0.52 & 0.6 \\
Body depth & -1.52 & -0.38 & 0.66 \\
Dairy form & -0.64 & 0.42 & 1.5 \\
Rump angle & -1.27 & 0.27 & 1.96 \\
Thurl width & -1.67 & -0.35 & 1.04 \\
Feet and legs score & -1.27 & 0.03 & 1.1 \\
Rear legs side view & -1.34 & 0.2 & 1.47 \\
Rear legs rear view & -1.46 & 0.11 & 1.14 \\
Foot angle & -1.4 & -0.2 & 0.95 \\
Fore udder attachment & -1.71 & -0.13 & 1.03 \\
Udder cleft & -1.58 & 0.16 & 0.56 \\
Udder depth & -1.77 & -0.49 & 3.25 \\
SCC & 2.85 & 3.04 & 1.8 \\
Rear udder width & -1.22 & 0.31 & \\
\hline
\end{tabular}

during the first LACT, during the second LACT, or during the third LACT are presented in Table 3. White line disease, SU, and DD incidence was significantly higher in cows that were affected with WLD, SU, or DD in the previous LACT. Cows that were affected with WLD or SU or DD during the first LACT had significantly higher WLD, SU, or DD incidence during the second and the third LACT. Additionally, cows that were affected with DD during the second LACT had significantly higher DD incidence during the third and the fourth-or-greater LACT.

Sole ulcer-adjusted incidence for different categorical fixed effects used in the model that evaluated the association of sire PTA for various traits and SU are presented in Table 4. Similar results regarding WLD- and DD-adjusted incidence are presented in Tables 5 and 6. Lower sire PTA for MY or PY was associated with lower daughters' incidence of foot lesions. Intermediate values for FA were correlated with the lowest incidence of SU, WLD, and DD. Higher sire PTA for RLRV was associated with lower SU incidence. Higher sire PTA for THRLW was associated with higher SU and DD incidence. Higher sire PTA for STR was associated with lower incidence of SU and DD. Higher sire PTA for FUA was associated with lower SU incidence, whereas higher PTA for RUH was associated with lower SU and DD incidence.

Adjusted ME305 MY by LACT during the first or the second LACT period are presented for cows affected or not with SU and WLD in Figures 1 and 2, respectively. Adjusted ME305 MY by LACT for cows that were affected or not with DD during the second LACT period and for cows that had at least 1 lesion (SU, WLD, or DD) during the first $3 \mathrm{LACT}$ or cows that had no lesions during the first $3 \mathrm{LACT}$ are presented in Figure 3. Cows that were affected with SU, WLD, or DD during their second LACT had higher second-LACT ME305 MY, whereas cows that were affected with SU or WLD during their first LACT had a significantly lower ME305 MY during the second LACT. Cows that had at least 1 lesion during their first 3 LACT had a significantly higher ME305 MY during these first 3

Table 2. Number of cows (n); sole ulcer (SU), white line disease (WLD), and digital dermatitis (DD) incidence (\%); and mean mature-equivalent 305-d (ME305) milk yield (kg) for each of the first 5 lactations

\begin{tabular}{|c|c|c|c|c|c|}
\hline Lactation & $\mathrm{n}$ & $\mathrm{SU}$ & WLD & DD & $\begin{array}{l}\text { ME305 } \\
\text { milk yield }\end{array}$ \\
\hline 1 & 11,442 & 4.3 & 3.2 & 9.2 & $12,921.86$ \\
\hline 2 & 7,507 & 15.8 & 7.9 & 11.4 & $13,024.49$ \\
\hline 3 & 4,069 & 21.4 & 12.2 & 8.7 & $11,778.41$ \\
\hline 4 & 1,647 & 22.8 & 12.4 & 7.7 & $10,647.50$ \\
\hline 5 & 507 & 22.3 & 10.3 & 6.3 & 9,999.34 \\
\hline
\end{tabular}


Table 3. Adjusted incidence (with $95 \%$ CI in parentheses) of foot lesions by cow lactation $(2,3$, and $\geq 4$ ), for cows that were affected (1) or were not affected (0) with white line disease (WLD), sole ulcer (SU), or digital dermatitis (DD) during the first, second, or third lactation

\begin{tabular}{|c|c|c|c|c|c|c|}
\hline \multirow[b]{2}{*}{ Lesion } & \multirow[b]{2}{*}{ Parity } & \multirow{2}{*}{$\begin{array}{l}\text { Lesion } \\
\text { status }\end{array}$} & \multicolumn{3}{|c|}{ Lactation-adjusted incidence } & \multirow[b]{2}{*}{$P$-value } \\
\hline & & & 2 & 3 & $\geq 4$ & \\
\hline \multirow[t]{6}{*}{ WLD } & 1 & 0 & $5.5(4.9-6.0)$ & $11.0(10.0-12.0)$ & $14.8(13.2-16.6)$ & \multirow{2}{*}{$<0.01$} \\
\hline & & 1 & $19.6(15.1-24.9)$ & $21.3(13.0-32.9)$ & $23.7(8.5-50.8)$ & \\
\hline & \multirow[t]{2}{*}{2} & 0 & & $9.0(8.0-10.0)$ & $12.8(11.4-14.4)$ & \multirow{2}{*}{$<0.01$} \\
\hline & & 1 & & $20.0(16.0-24.7)$ & $17.7(10.9-27.4)$ & \\
\hline & \multirow[t]{2}{*}{3} & 0 & & & $10.2(8.9-11.7)$ & \multirow{2}{*}{$<0.001$} \\
\hline & & 1 & & & $21.0(16.0-21.9)$ & \\
\hline \multirow[t]{6}{*}{$\mathrm{SU}$} & \multirow[t]{2}{*}{1} & 0 & $11.9(11.1-12.7)$ & $19.6(18.3-21.0)$ & $26.2(24.1-28.4)$ & \multirow{2}{*}{$<0.001$} \\
\hline & & 1 & $43.9(38.4-49.5)$ & $31.6(24.7-39.5)$ & $22.8(13.8-35.2)$ & \\
\hline & \multirow[t]{2}{*}{2} & 0 & & $14.8(13.5-16.1)$ & $23.5(21.5-25.6)$ & \multirow{2}{*}{$<0.001$} \\
\hline & & 1 & & $39.9(36.1-43.9)$ & $30.0(24.5-36.2)$ & \\
\hline & \multirow[t]{2}{*}{3} & 0 & & & $18(16.18-19.98)$ & \multirow{2}{*}{$<0.001$} \\
\hline & & 1 & & & $41.4(36.3-46.8)^{\prime}$ & \\
\hline \multirow[t]{6}{*}{ DD } & \multirow[t]{2}{*}{1} & 0 & $6.6(6.0-7.2)$ & $6.8(6.0-7.7)$ & $7.5(6.3-8.8)$ & \multirow{2}{*}{$<0.001$} \\
\hline & & 1 & $31.9(28.5-35.4)$ & $14.5(11.8-17.9)$ & $10.2(6.9-14.8)$ & \\
\hline & \multirow[t]{2}{*}{2} & 0 & & $5.0(4.3-5.8)$ & $6.6(5.6-7.9)$ & \multirow{2}{*}{$<0.001$} \\
\hline & & 1 & & $19.2(16.0-22.8)$ & $12.4(9.1-16.8)$ & \\
\hline & \multirow[t]{2}{*}{3} & 0 & & & $5.3(4.4-6.5)$ & \multirow{2}{*}{$<0.001$} \\
\hline & & 1 & & & $14.1(10-19.6)$ & \\
\hline
\end{tabular}

LACT and significantly lower milk production in the fourth LACT compared with cows that never developed a lameness lesion.

Cows that were affected with SU or WLD during the first LACT were 1.18 (95\% CI: 1.06-1.30) or $1.43(95 \%$ CI: $1.27-1.59)$ times more likely to be culled earlier than their unaffected counterparts. Digital dermatitis incidence during the first LACT was not found to significantly affect survivability.

\section{DISCUSSION}

The risk of SU and WLD increased gradually with LACT number. Gernand et al. (2012) also reported an increasing incidence of SU and WLD by parity. This was also the case for WLD in Potzsch et al. (2003) study. Bicalho et al. (2009) showed that digital cushion thickness is highly associated with BCS and a strong predictor of lameness. Machado et al. (2011) confirmed these findings reporting that low BCS and low digital cushion thickness at drying off were significant risk factors for CHDL during the subsequent LACT. It is known that multiparous cows usually experience a negative energy balance period of greater magnitude and duration and, hence, they usually have lower BCS compared with primiparous cows (Wathes et al., 2007). Therefore, they are also expected to have lower digital cushion thickness and this fact could provide a possible explanation for the observed increased incidence in $\mathrm{SU}$ and WLD in multiparous cows. There may also be an effect of cow comfort and reduced resting time that manifests in an increase in the incidence of claw le- sions in multiparous cows (Cook and Nordlund, 2009). Although cows continue to increase in size with LACT number, particularly with the historic selection for increased MY (Hansen, 2000), stall sizes remain unchanged in the majority of freestall facilities. Restricted stall dimensions have been shown to alter stall use behavior (e.g., Tucker et al., 2004), which may affect the rate of lesion development and resolution in larger older cows.

Conversely, DD incidence was higher during the second LACT and decreased during the subsequent LACT. This is in agreement with results presented by Somers et al. (2005), Holzhauer et al. (2006), and Nielsen et al. (2012). Digital dermatitis is an infectious disease and decreased incidence in older cows might be related to increased local immunity.

Machado et al. (2011), using data from 574 cows, recently reported that cows detected with SU or WLD at cessation of LACT had an incidence of CHDL of $43.8 \%$ in the subsequent LACT, whereas the incidence for cows without lesions was $9.6 \%$. In the present study, the repeatability of all studied lesions (DD, SU, and WLD) was high; previous LACT incidence of DD, SU, and WLD was a strong predictor of future LACT incidence of the same lesions. The notion that CHDL are usually chronic disease processes with a high recurrence rate already has been put forward (Whay et al., 2003; Guard 2008; Machado et al., 2011) and is corroborated by results presented in this study. Additionally, Hirst et al. (2002) reported that cows affected with CHDL during their first LACT were at a 3.2 times increased hazard of developing similar lesions in the subsequent 
Table 4. Sole ulcer (SU) adjusted incidence (with 95\% CI in parentheses) for categorical fixed effects (terciles created for different sire predicted transmitting ability values) used in the logistic regression model that was fitted to the data using PROC GLIMMIX of SAS $\left(\right.$ SAS Institute Inc., Cary, NC) ${ }^{1}$

\begin{tabular}{|c|c|c|c|}
\hline $\begin{array}{l}\text { Predicted } \\
\text { transmitting ability }\end{array}$ & Tercile & $\begin{array}{l}\text { SU-adjusted } \\
\text { incidence }\end{array}$ & $P$-value \\
\hline \multirow[t]{3}{*}{ Milk yield } & 1 & $3.8(3.2-4.5)$ & \multirow{3}{*}{$<0.0001$} \\
\hline & 2 & $7.1(6.3-8.0)$ & \\
\hline & 3 & $6.3(5.4-7.4)$ & \\
\hline \multirow[t]{3}{*}{ Protein yield } & 1 & $4.1(3.5-4.7)$ & \multirow{3}{*}{$<0.0001$} \\
\hline & 2 & $5.5(4.9-6.2)$ & \\
\hline & 3 & $7.6(6.5-8.8)$ & \\
\hline \multirow[t]{3}{*}{ Body depth } & 1 & $7.9(6.8-9.2)$ & \multirow{3}{*}{$<0.0001$} \\
\hline & 2 & $5.5(4.9-6.2)$ & \\
\hline & 3 & $3.9(3.2-4.6)$ & \\
\hline \multirow[t]{3}{*}{ Feet and legs score } & 1 & $3.4(2.8-4.2)$ & \multirow{3}{*}{$<0.0001$} \\
\hline & 2 & $6.9(6.1-7.9)$ & \\
\hline & 3 & $7.1(5.8-8.6)$ & \\
\hline \multirow[t]{3}{*}{ Foot angle } & 1 & $6.6(5.7-7.7)$ & \multirow{3}{*}{$<0.0001$} \\
\hline & 2 & $3.8(3.3-4.5)$ & \\
\hline & 3 & $6.6(5.6-7.9)$ & \\
\hline \multirow[t]{3}{*}{ Fore udder attachment } & 1 & $5.4(4.6-6.9)$ & \multirow{3}{*}{$<0.0001$} \\
\hline & 2 & $6.7(6.0-7.5)$ & \\
\hline & 3 & $4.7(4.0-5.5)$ & \\
\hline \multirow[t]{3}{*}{ Rear legs rear view } & 1 & $7.4(6.3-8.6)$ & \multirow{3}{*}{$<0.001$} \\
\hline & 2 & $5.2(4.6-5.8)$ & \\
\hline & 3 & $4.5(3.7-5.3)$ & \\
\hline \multirow[t]{3}{*}{ Rear udder height } & 1 & $7.4(5.9-9.3)$ & \multirow{3}{*}{$<0.05$} \\
\hline & 2 & $5.5(4.7-6.4)$ & \\
\hline & 3 & $4.2(3.4-5.2)$ & \\
\hline \multirow[t]{3}{*}{ Rear udder width } & 1 & $3.8(2.9-4.9)$ & \multirow{3}{*}{$<0.0001$} \\
\hline & 2 & $7.7(6.7-8.7)$ & \\
\hline & 3 & $5.8(4.8-7.1)$ & \\
\hline \multirow[t]{3}{*}{ Strength } & 1 & $6.9(5.8-8.1)$ & \multirow{3}{*}{$<0.001$} \\
\hline & 2 & $6.4(5.6-7.4)$ & \\
\hline & 3 & $3.8(3.1-4.7)$ & \\
\hline \multirow[t]{3}{*}{ Thurl width } & 1 & $4.2(3.6-4.7)$ & \multirow{3}{*}{$<0.0001$} \\
\hline & 2 & $5.0(4.4-5.6)$ & \\
\hline & 3 & $8.2(7.3-9.3)$ & \\
\hline
\end{tabular}

${ }^{1}$ Sole ulcer incidence was the dependent variable.

LACT. Nielsen et al. (2012) reported the existence of cows with repeated, persisting DD lesions. Guard (2008) also reported that reoccurrence of a DD lesion is rather common and we show here that cows affected with DD are more likely to be affected with DD again even 2 LACT later. In a recently published study, Oberbauer et al. (2013) also reported high repeatability estimates for SU, WLD, and DD.

Previous genetic studies have already revealed the genetic correlations between several conformation traits and lameness or specific foot lesions. Foot angle has been reported to have a negative genetic correlation with lameness and, therefore, selection for higher FA scores may lead to improved genetic resistance to lameness (Boettcher et al., 1998; Van Dorp et al., 1998; van der Waaij et al., 2005). Koenig et al. (2005) showed a similar genetic correlation between FA and SU. Sire PTA for FA was found in the present study to be significantly associated with SU, WLD, and DD. In the present study, FA was not analyzed as a continuous
Table 5. White line disease (WLD) adjusted incidence (with $95 \%$ CI in parentheses) for categorical fixed effects (terciles created for different sire predicted transmitting ability values) used in the logistic regression model that was fitted to the data using PROC GLIMMIX of SAS (SAS Institute Inc., Cary, NC) ${ }^{1}$

\begin{tabular}{lccc}
\hline $\begin{array}{l}\text { Predicted } \\
\text { transmitting ability }\end{array}$ & Tercile & $\begin{array}{c}\text { WLD-adjusted } \\
\text { incidence }\end{array}$ & $P$-value \\
\hline Milk yield & 1 & $3.2(2.7-3.7)$ & \\
& 2 & $4.3(3.8-4.8)$ & $<0.001$ \\
Protein yield & 3 & $3.3(2.8-3.8)$ & \\
& 1 & $2.7(2.3-3.1)$ & \\
Foot angle & 2 & $3.5(3.0-4.0)$ & $<0.001$ \\
& 3 & $4.7(4.0-5.6)$ & \\
Rear udder height & 1 & $4.8(4.2-5.6)$ & \\
& 2 & $2.9(2.5-3.3)$ & $<0.001$ \\
Strength & 3 & $3.2(2.8-3.8)$ & \\
& 1 & $2.3(1.9-2.8)$ & \\
& 2 & $4.1(3.5-4.7)$ & $<0.001$ \\
& 3 & $4.8(4.2-5.5)$ & \\
& 1 & $2.6(2.1-3.2)$ & $<0.001$ \\
\end{tabular}

${ }^{1}$ White line disease incidence was the dependent variable.

Table 6. Digital dermatitis (DD) adjusted incidence (with $95 \%$ CI in parentheses) for categorical fixed effects (terciles created for different sire predicted transmitting ability values) used in the logistic regression model that was fitted to the data using PROC GLIMMIX of SAS (SAS Institute Inc., Cary, NC) ${ }^{1}$

\begin{tabular}{|c|c|c|c|}
\hline $\begin{array}{l}\text { Predicted } \\
\text { transmitting ability }\end{array}$ & Tercile & $\begin{array}{l}\text { DD-adjusted } \\
\text { incidence }\end{array}$ & $P$-value \\
\hline \multirow[t]{3}{*}{ Milk yield } & 1 & $3.2(2.7-3.8)$ & \multirow{3}{*}{$<0.001$} \\
\hline & 2 & $6.2(5.5-7.0)$ & \\
\hline & 3 & $6.8(5.8-7.9)$ & \\
\hline \multirow[t]{3}{*}{ Fat yield } & 1 & $7.4(6.6-8.3)$ & \multirow{3}{*}{$<0.001$} \\
\hline & 2 & $5.6(5.0-6.4)$ & \\
\hline & 3 & $3.2(2.7-3.8)$ & \\
\hline \multirow[t]{3}{*}{ Feet and legs score } & 1 & $4.2(3.6-4.9)$ & \multirow{3}{*}{$<0.001$} \\
\hline & 2 & $6.3(5.6-7.1)$ & \\
\hline & 3 & $5.1(4.3-6.1)$ & \\
\hline \multirow[t]{3}{*}{ Foot angle } & 1 & $6.3(5.3-7.4)$ & \multirow{3}{*}{$<0.001$} \\
\hline & 2 & $3.3(2.8-3.8)$ & \\
\hline & 3 & $6.4(5.4-7.7)$ & \\
\hline \multirow[t]{3}{*}{ Fore udder attachment } & 1 & $3.3(2.7-3.9)$ & \multirow{3}{*}{$<0.001$} \\
\hline & 2 & $4.8(4.2-5.5)$ & \\
\hline & 3 & $8.4(7.2-9.9)$ & \\
\hline \multirow[t]{3}{*}{ Rear udder height } & 1 & $12.4(10.2-15.1)$ & \multirow{3}{*}{$<0.001$} \\
\hline & 2 & $5.1(4.4-5.9)$ & \\
\hline & 3 & $2.0(1.6-2.5)$ & \\
\hline \multirow[t]{3}{*}{ Rear udder width } & 1 & $3.2(2.5-4.0)$ & \multirow{3}{*}{$<0.001$} \\
\hline & 2 & $7.3(6.5-8.2)$ & \\
\hline & 3 & $5.8(4.8-7.0)$ & \\
\hline \multirow[t]{3}{*}{ Stature } & 1 & $7.7(6.7-8.8)$ & \multirow{3}{*}{$<0.001$} \\
\hline & 2 & $4.4(3.8-5.0)$ & \\
\hline & 3 & $4.0(3.5-4.6)$ & \\
\hline \multirow[t]{3}{*}{ Strength } & 1 & $7.2(6.3-8.3)$ & \multirow{3}{*}{$<0.001$} \\
\hline & 2 & $5.9(5.1-6.7)$ & \\
\hline & 3 & $3.2(2.6-3.8)$ & \\
\hline \multirow[t]{3}{*}{ Thurl width } & 1 & $3.9(3.2-4.4)$ & \multirow{3}{*}{$<0.001$} \\
\hline & 2 & $5.9(4.5-5.8)$ & \\
\hline & 3 & $7.0(6.1-8.8)$ & \\
\hline \multirow[t]{3}{*}{ Udder cleft } & 1 & $3.6(3.9-4.2)$ & \multirow{3}{*}{$<0.001$} \\
\hline & 2 & $7.4(6.5-8.3)$ & \\
\hline & 3 & $5.1(4.9-5.9)$ & \\
\hline
\end{tabular}

${ }^{1}$ Digital dermatitis incidence was the dependent variable. 

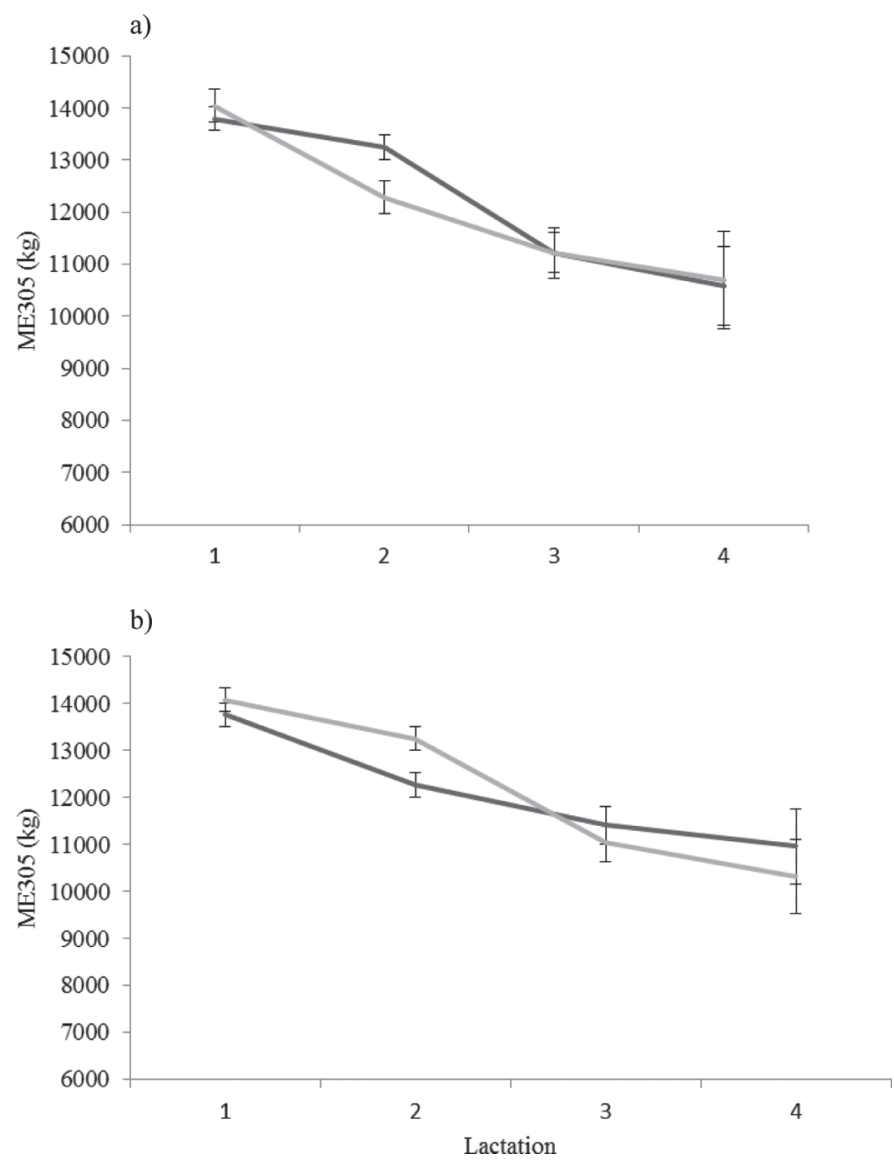

Figure 1. Adjusted means and respective 95\% CI of the means (error bars) of mature-equivalent 305-d milk yield (ME305) by lactation for cows that were (light gray line) or were not (dark gray line) affected with sole ulcers during the first (1a) and the second (1b) lactation.

variable, as previously reported, but categorized into terciles (low, medium, and high values), allowing us to demonstrate that it is the intermediate values (medium tercile for which the mean standardized PTA was -0.2 , ranging from -0.7 to 0.3 ) for $\mathrm{FA}$ that are correlated with the lowest incidence of SU, WLD, and DD. Norman et al. (1996) reported a phenotypic intermediate optimum for FA. We report here that the higher the RLRV sire PTA, the lower the SU incidence among their daughters. Similarly, Koenig et al. (2005) and Boettcher et al. (1998) reported a negative genetic correlation between RLRV and SU or lameness. Selection for higher RLRV actually means selection for straighter hind legs. Higher sire PTA for THRLW in the present study was associated with higher SU and DD incidence. Boettcher et al. (1998) reported an unfavorable genetic relationship between THRLW and lameness. It can be speculated that this association may be due to certain effects on the biomechanics of locomotion that greater THRLW may have. High sire PTA for STR was associated with lower incidence of SU and DD. On the other a)

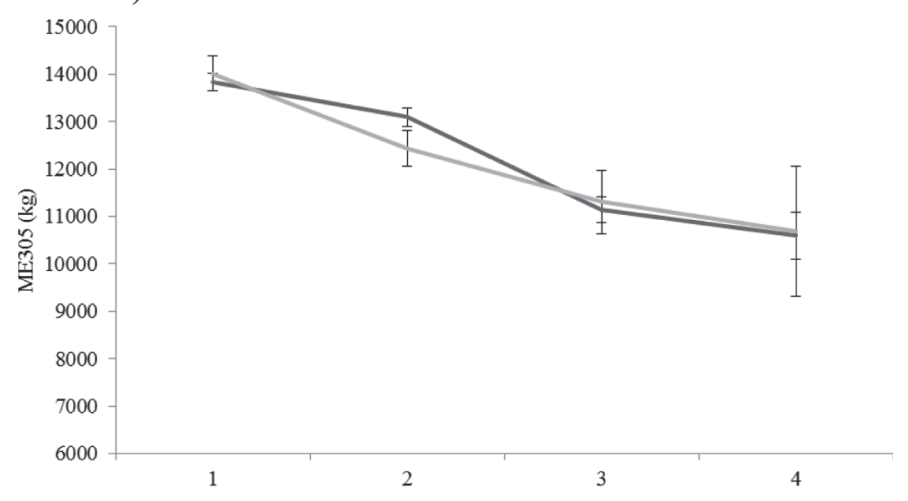

b)

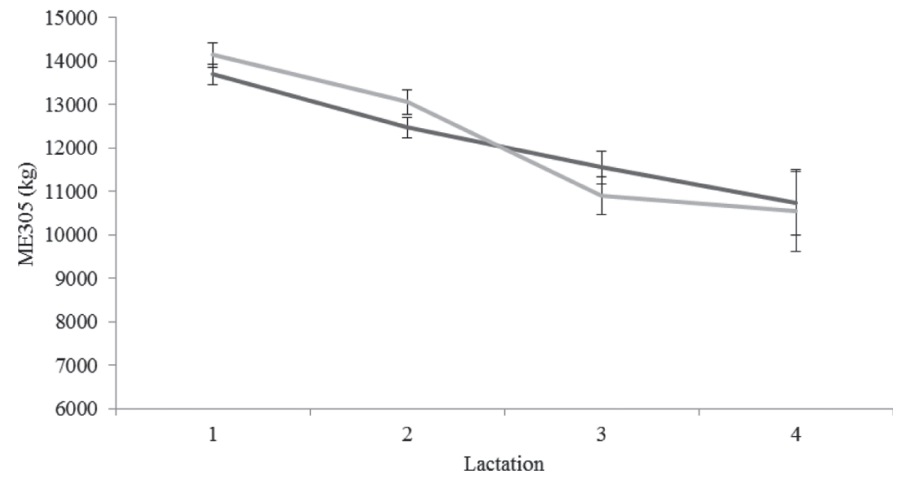

Figure 2. Adjusted means and respective 95\% CI of the means (error bars) of mature-equivalent 305-d milk yield (ME305) by lactation for cows that were (light gray line) or were not (dark gray line) affected with white line disease during the first (2a) and the second (2b) lactation.

hand, Boettcher et al. (1998) reported an unfavorable genetic correlation between STR and clinical lameness, suggesting that stronger, wider cows are more susceptible to the disease. The same authors also reported that well-attached udders were associated with decreased lameness. In our study, higher sire PTA for FUA was associated with lower SU incidence and high PTA for RUH was associated with lower SU and DD incidence.

The detrimental effect of lameness on milk production has already been shown. Green et al. (2002) reported a $360-\mathrm{kg}$ reduction in MY per 305-d LACT. Bicalho et al. (2008) reported a reduction that could reach $424 \mathrm{~kg}$ for cows affected with CHDL. Amory et al. (2008) concluded that SU and WLD were associated with significant milk production losses, whereas DD was not. The aforementioned effects were limited to the LACT period during which a lameness event was recorded. Using multiple-LACT data, we provide here additional information on the interrelationships of MY and foot lesions. Cows that were affected with SU or WLD during their first LACT had a significantly lower ME305 MY during the second LACT. A similar 


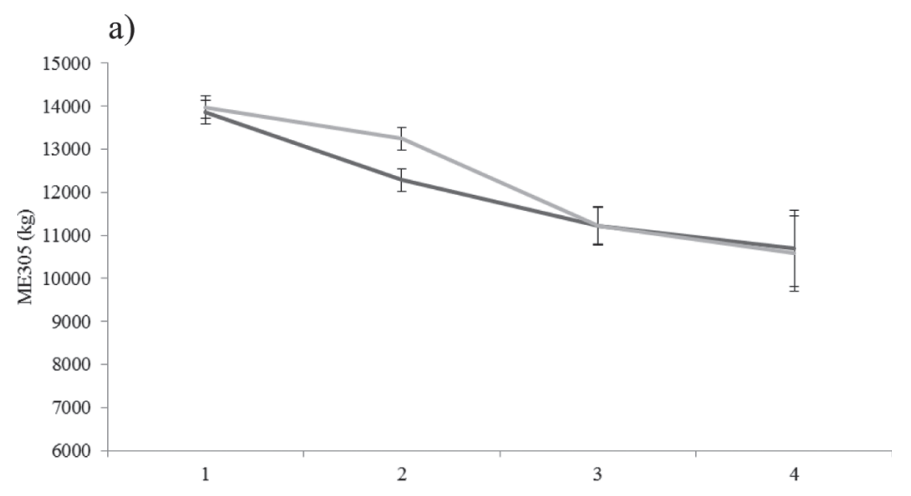

b)

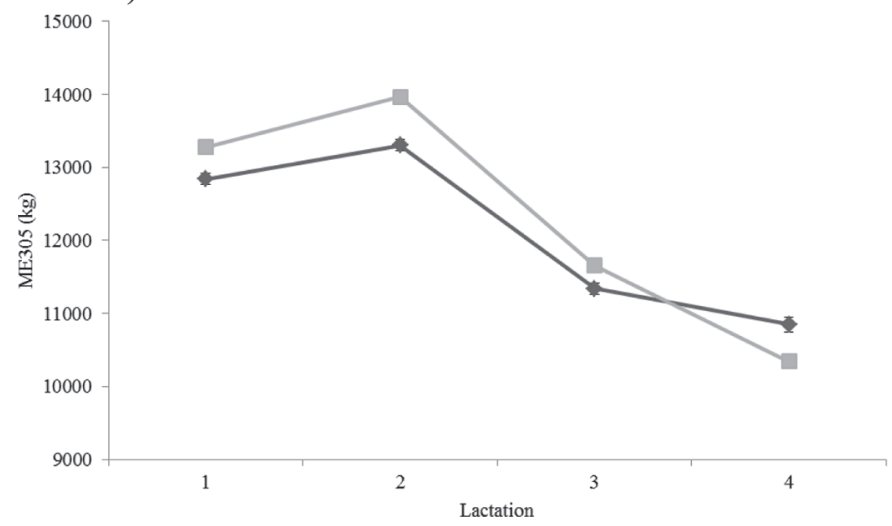

Figure 3. Least squares means and respective 95\% CI of the means (error bars) of mature-equivalent 305 milk yield (ME305) by lactation for cows that were (light gray line) or were not (dark gray line) affected with digital dermatitis during the second lactation (3a) and for cows that had at least 1 lesion (sole ulcer, white line lesions, or digital dermatitis; light gray line) during the first 3 lactation periods and cows that had no lesions (dark gray line) during the first 3 lactation $(3 \mathrm{~b})$.

observation was made for cows that suffered from SU or WLD during the second LACT, but the difference did not obtain statistical significance.

High milk production has been shown to be a significant risk factor for lameness (Green et al., 2002; Koenig et al., 2005; Onyiro et al., 2008), whereas in the Amory et al. (2008) study, it was a significant risk factor for SU and WLD but not for DD. Bicalho et al. (2008) reported that cows affected with SU, WLD, toe ulcers, or other similar lesions that were treated with orthopedic blocks produced $3.2 \mathrm{~kg} / \mathrm{d}$ more milk than nonlame cows during the first 3 wk of LACT. In the present study, similar observations were made, especially for second-LACT cows. Cows that were affected with SU, WLD, or DD during their second LACT had higher second-LACT ME305 MY. Given the detrimental effect of lameness on MY, these results suggest that these cows were higher producers before they become lame. Cows that had at least 1 lesion during their first 3 LACT also had a significantly higher ME305 MY during these first 3 LACT compared with cows that never developed a lameness lesion.

Evidence exists that these observations are partially due to genetics. Studies have already shown a positive (unfavorable) genetic relationship between milk production and lameness, suggesting that cows of higher genetic merit for milk production are also more prone to develop lameness (Lyons et al., 1991; Van Dorp et al., 1998). Kougioumtzis et al. (2011) also reported a strong (0.75) significant genetic correlation between MY and lameness. We show here that cows whose sires had lower PTA for milk production were also cows with lower adjusted incidence of SU, WLD, and DD. Sire PTA for PY was also a significant risk factor for SU and WLD. The above-mentioned genetic relationships as well as results presented here regarding the association between sire PTA for production traits and foot lesions incidence suggest that higher genetic merit for production is a significant risk factor for lameness. In other words, continuous selection for higher milk and protein production without considering lameness or lameness-related traits in the breeding goal will lead to deteriorated claw health. Milk yield is known to have a negative genetic correlation with BCS (Loker et al., 2012), whereas low BCS is phenotypically (Bicalho et al., 2009) and genetically (Van Dorp et al., 1998; Kougioumtzis et al., 2011) associated with increased susceptibility to lameness. It is possible that selecting for high-producing cows that will at the same time better maintain their BCS level, may also contribute to the genetic improvement of cows' resistance to lameness. Interestingly, DF, a trait known to be genetically and phenotypically negatively correlated with BCS (Dechow et al., 2004), was not found to be associated with any of the studied lesions. However, dairy form is admittedly correlated with BCS but it is not the same trait. It is possible that genetic evaluations for BCS per se may be more informative as far as lameness prevention through genetic selection is concerned. It should also be noted here that the averages for terciles 1 and 3 were less extreme for DF than for other type traits and this may be an explanation for the lack of any associations between DF and the lesions studied here.

Sole ulcers and WLD during the first LACT were found to have a significant detrimental effect on cow survivability. Booth et al. (2004) and Bicalho et al. (2007) already reported that lameness had an adverse effect on cow survivability using data for the LACT during which the lameness event was recorded. Here, we used multiple-LACT data and the effects of SU1 and WLD1 still remained significant. Booth et al. (2004) analyzed the effect of specific foot lesions and, in agreement with results presented here, reported a significant effect of SU on survivability, whereas DD had 
no significant effect. Cramer et al. (2009) also reported that WLD and SU significantly increased the risk of culling, whereas infectious lesions had no significant association with it. It should be mentioned that, in the present study, ME305 MY was included in the model that estimated lesion effects on survivability and that before this inclusion, the obtained results suggested a positive effect of SU and WLD on cow survivability. Cows producing less milk are more likely to be culled; on the other hand, they are also less likely to become lame. Therefore, milk production may be considered as a confounder in the estimation of lameness effects on survivability (Booth et al., 2004).

\section{CONCLUSIONS}

We show here that certain foot lesions are highly repeatable across LACT and may have long-term effects on cow survivability and productivity. High milk production and high-production genetic potential are risk factors for specific claw disorders. Additionally, the possible role of genetic selection for lameness resistance is highlighted. For example, selection for intermediate scores of FA and higher scores of STR or RLRV may result in lower $\mathrm{SU}$ incidence.

\section{REFERENCES}

Amory, J. R., Z. E. Barker, J. L. Wright, S. A. Mason, R. W. Blowey, and L. E. Green. 2008. Associations between sole ulcer, white line disease and digital dermatitis and the milk yield of 1824 dairy cows on 30 dairy cow farms in England and Wales from February 2003-November 2004. Prev. Vet. Med. 83:381-391.

Bicalho, R. C., V. S. Machado, and L. S. Caixeta. 2009. Lameness in dairy cattle: A debilitating disease or a disease of debilitated cattle? A cross-sectional study of lameness prevalence and thickness of the digital cushion. J. Dairy Sci. 92:3175-3184.

Bicalho, R. C., F. Vokey, H. N. Erb, and C. L. Guard. 2007. Visual locomotion scoring in the first seventy days in milk: Impact on pregnancy and survival. J. Dairy Sci. 90:4586-4591.

Bicalho, R. C., L. D. Warnick, and C. L. Guard. 2008. Strategies to analyze milk losses caused by diseases with potential incidence throughout the lactation: A lameness example. J. Dairy Sci. 91:2653-2661.

Boettcher, P. J., J. C. Dekkers, L. D. Warnick, and S. J. Wells. 1998. Genetic analysis of clinical lameness in dairy cattle. J. Dairy Sci. 81:1148-1156.

Booth, C. J., L. D. Warnick, Y. T. Gröhn, D. O. Maizon, C. L. Guard, and D. Janssen. 2004. Effect of lameness on culling in dairy cows. J. Dairy Sci. 87:4115-4122.

Cha, E., J. A. Hertl, D. Bar, and Y. T. Gröhn. 2010. The cost of different types of lameness in dairy cows calculated by dynamic programming. Prev. Vet. Med. 97:1-8.

Cook, N. B., and K. V. Nordlund. 2009. The influence of the environment on dairy cow behavior, claw health and herd lameness dynamics. Vet. J. 179:360-369.

Cramer, G., K. D. Lissemore, C. L. Guard, K. E. Leslie, and D. F. Kelton. 2009. The association between foot lesions and culling risk in Ontario Holstein cows. J. Dairy Sci. 92:2572-2579.

Dechow, C. D., G. W. Rogers, L. Klei, T. J. Lawlor, and P. M. VanRaden. 2004. Body condition scores and dairy form evaluations as indicators of days open in US Holsteins. J. Dairy Sci. 87:35343541.

Gernand, E., P. Rehbein, U. U. von Borstel, and S. König. 2012. Incidences of and genetic parameters for mastitis, claw disorders, and common health traits recorded in dairy cattle contract herds. J. Dairy Sci. 95:2144-2156.

Green, L. E., V. J. Hedges, Y. H. Schukken, R. W. Blowey, and A. J. Packington. 2002. The impact of clinical lameness on the milk yield of dairy cows. J. Dairy Sci. 85:2250-2256.

Guard, C. 2008. Musculoskeletal disorders. Pages 467-503 in Rebhun's Diseases of Dairy Cattle. 2nd ed. Saunders Elsevier. St. Louis, MO.

Hansen, L. B. 2000. Consequences of selection for milk yield from a geneticist's viewpoint. J. Dairy Sci. 83:1145-1150.

Hirst, W. M., R. D. Murray, W. R. Ward, and N. P. French. 2002. A mixed-effects time-to-event analysis of the relationship between first-lactation lameness and subsequent lameness in dairy cows in the UK. Prev. Vet. Med. 54:191-201.

Holzhauer, M., C. Hardenberg, C. J. Bartels, and K. Frankena. 2006. Herd- and cow-level prevalence of digital dermatitis in the Netherlands and associated risk factors. J. Dairy Sci. 89:580-588.

Koenig, S., A. R. Sharifi, H. Wentrot, D. Landmann, M. Eise, and H. Simianer. 2005. Genetic parameters of claw and foot disorders estimated with logistic models. J. Dairy Sci. 88:3316-3325.

Kougioumtzis, A., G. Oikonomou, G. Arsenos, and G. Banos. 2011. Genetic relationship of lameness with milk yield, body condition score and reproductive traits in primiparous Holstein cows. Page 13 in Proc. 126th Annu. Conf. British Soc. Anim. Sci. British Society of Animal Science, Penicuik, Midlothian, UK.

Loker, S., C. Bastin, F. Miglior, A. Sewalem, L. R. Schaeffer, J. Jamrozik, A. Ali, and V. Osborne. 2012. Genetic and environmental relationships between body condition score and milk production traits in Canadian Holsteins. J. Dairy Sci. 95:410-419.

Lyons, D. T., A. E. Freeman, and A. L. Luck. 1991. Genetics of health traits in cattle. J. Dairy Sci. 74:1092-1100.

Machado, V. S., L. S. Caixeta, and R. C. Bicalho. 2011. Use of data collected at cessation of lactation to predict incidence of sole ulcers and white line disease during the subsequent lactation in dairy cows. Am. J. Vet. Res. 72:1338-1343.

Machado, V. S., L. S. Caixeta, J. A. McArt, and R. C. Bicalho. 2010. The effect of claw horn disruption lesions and body condition score at dry-off on survivability, reproductive performance, and milk production in the subsequent lactation. J. Dairy Sci. 93:40714078.

Nielsen, B. H., P. T. Thomsen, L. E. Green, and J. Kaler. 2012. A study of the dynamics of digital dermatitis in 742 lactating dairy cows. Prev. Vet. Med. 104:44-52.

Norman, H. D., R. L. Powell, J. R. Wright, and R. E. Pearson. 1996. Phenotypic relationship of yield and type scores from first lactation with herd life and profitability. J. Dairy Sci. 79:689-701.

Oberbauer, A. M., S. L. Berry, J. M. Belanger, R. M. McGoldrick, J. M. Pinos-Rodriquez, and T. R. Famula. 2013. Determining the heritable component of dairy cattle foot lesions. J. Dairy Sci. 96:605-613.

Onyiro, O. M., J. Offer, and S. Brotherstone. 2008. Risk factors and milk yield losses associated with lameness in Holstein-Friesian dairy cattle. Animal 2:1230-1237.

Pötzsch, C. J., V. J. Collis, R. W. Blowey, A. J. Packington, and L. E. Green. 2003. The impact of parity and duration of biotin supplementation on white line disease lameness in dairy cattle. J. Dairy Sci. 86:2577-2582.

Somers, J. G., K. Frankena, E. N. Noordhuizen-Stassen, and J. H. Metz. 2005. Risk factors for digital dermatitis in dairy cows kept in cubicle houses in the Netherlands. Prev. Vet. Med. 71:11-21.

Swalve, H. H., H. Alkhoder, and R. Pijl. 2008. Estimates of breeding values for sires based on diagnoses recorded at hoof trimming: Relationships with EBV for conformation traits. Interbull Bull. 38:87-90.

Tucker, C. B., D. M. Weary, and D. Fraser. 2004. Freestall dimensions: Effects on preference and stall usage. J. Dairy Sci. 87:1208-1216. 
Uggla, E., J. H. Jakobsen, C. Bergsten, J.-A. Eriksson, and E. Strandberg. 2008. Genetic correlations between claw health and feet and leg conformation traits in Swedish dairy cows. Interbull Bull. 38:91-95.

van der Linde, C., G. de Jong, E. P. Koenen, and H. Eding. 2010. Claw health index for Dutch dairy cattle based on claw trimming and conformation data. J. Dairy Sci. 93:4883-4891.

van der Waaij, E. H., M. Holzhauer, E. Ellen, C. Kamphuis, and G. de Jong. 2005. Genetic parameters for claw disorders in Dutch dairy cattle and correlations with conformation traits. J. Dairy Sci. 88:3672-3678

Van Dorp, T. E., J. C. Dekkers, S. W. Martin, and J. P. Noordhuizen. 1998. Genetic parameters of health disorders, and relationships with 305-day milk yield and conformation traits of registered Holstein cows. J. Dairy Sci. 81:2264-2270. von Keyserlingk, M. A., J. Rushen, A. M. de Passillé, and D. M. Weary. 2009. Invited review: The welfare of dairy cattle-Key concepts and the role of science. J. Dairy Sci. 92:4101-4111.

Wathes, D. C., Z. Cheng, N. Bourne, V. J. Taylor, M. P. Coffey, and S. Brotherstone. 2007. Differences between primiparous and multiparous dairy cows in the inter-relationships between metabolic traits, milk yield and body condition score in the periparturient period. Domest. Anim. Endocrinol. 33:203-225.

Whay, H. R., D. C. Main, L. E. Green, and A. J. Webster. 2003. Assessment of the welfare of dairy cattle using animal-based measurements: Direct observations and investigation of farm records. Vet. Rec. 153:197-202. 